\title{
Forest restoration activities with the indigenous community in Maranhão
}

\author{
Marques, A.R ${ }^{1}$; Amorim, $A^{1}$.; Fonseca, A.A.P. ${ }^{1}$ \\ ${ }^{1}$ Instituto Brasileiro de Meio Ambiente e Recursos Naturais Renováveis (Ibama), SUPES/Maranhão, \\ Brasil. *E-mail para contato: anclaros@yahoo.com.br
}

\begin{abstract}
This study presents the activities related to the forest fire prevention process and the implementation of agroforestry systems in Indigenous Lands where there is the work of the Prevfogo indigenous brigades. This process began in 2017 at TI Araribóia, in Aldeia Jussaral, with the planting of native species in an area comprising the right bank of the Buriticupu River, which was in an advanced stage of environmental degradation caused by annual fires. About 200 seedlings of the species Jussara (popular name) were planted on the site, which was now monitored by indigenous brigade members. In 2018, there was continuity of activities to encourage the restoration of degraded areas through Environmental Education workshops, which culminated in the establishment of nurseries for the production of seedlings of native species in all Indigenous Lands that have the brigade program. in Maranhão. These nurseries were implemented through the state coordination of Prevfogo. The assessment of the development of these actions took place through on-site technical visits and monthly monitoring, with the partner of the brigade members and indigenous associations. As a result we have the continuity of the restoration of the riparian forests of the Buriticupu River, in the Araribóia TI, the beginning of restoration of springs in the Indigenous Lands: Governor, Porquinhos, Caru. In addition, informal reports on the reduction of hot flashes due to awareness of this issue among these populations. In this sense, it was found that the actions planned in conjunction with the local communities make it possible to improve the environment as a whole and raise awareness of the reduction in the number of forest fires and fires.
\end{abstract}

Keywords: forest recovery; awareness; seedling production. 